DOI https://doi.org/10.1055/s-0043-104701

Published online: 19.9.2017

Exp Clin Endocrinol Diabetes

(c) J. A. Barth Verlag in Georg Thieme Verlag KG Stuttgart - New York 


\section{Polycystic ovary syndrome (PCOS) in juvenile and adult type 1 diabetes in a German/Austrian cohort}

Reinauer C. ${ }^{1}$, Bollow E. ${ }^{2}$, Fröhlich-Reiterer E. ${ }^{3}$, Laubner K. ${ }^{4}$, Bergis D. ${ }^{5}$, Schöfl C. ${ }^{6}$, Kempe H.-P.7, Hummel M. ${ }^{8}$, Hennes P. ${ }^{9}$, Gollisch K. ${ }^{10}$, Haberland H. ${ }^{11}$, Datz, N. ${ }^{12}$, Meissner T. ${ }^{1}$, Holl RW. ${ }^{2}$

${ }^{1}$ Department of General Pediatrics, Neonatology and Pediatric Cardiology, University Children's Hospital, Heinrich Heine University Düsseldorf, Düsseldorf, Germany,

Mail: christina.reinauer@med.uni-duesseldorf.de, Phone: 0211-8117687,Fax: 0211-8119512

2 Institute of Epidemiology and Medical Biometry, ZIBMT, University of Ulm, Ulm, Germany

${ }^{3}$ Department of Paediatrics, Medical University of Graz, Austria

${ }^{4}$ Division of Endocrinology and Diabetology, Department of Internal Medicine II, University Hospital of Freiburg, Freiburg, Germany

${ }^{5}$ Department of Internal Medicine 1, University Hospital Frankfurt, Goethe University, Frankfurt am Main, Germany.

${ }^{6}$ Centres of Endocrinology and Metabolism, Bamberg and Erlangen, Germany

${ }^{7}$ Specialized Diabetes Practice Diabetologikum, Ludwigshafen, Germany

${ }^{8}$ Specialized Diabetes Practice, Rosenheim, Germany

${ }^{9}$ Department of Pediatrics, Saarland University, Homburg, Germany

${ }^{10}$ Clinic for Gastroenterology and Gastrointestinal Oncology, Endocrine Unit, University Medical Center Göttingen, Göttingen, Germany

${ }^{11}$ Hospital for Children and Adolescents, Sana Hospital Berlin Lichtenberg, Berlin, Germany

${ }^{12}$ Diabetes Center for Children and Adolescents, Children's Hospital Auf der Bult, Hannover, Germany 


\section{Abstract}

Context: While an association between PCOS and type 2 diabetes is well established, to date there have been few data on clinical care of type 1 diabetes (T1D) patients with PCOS.

Objective: The aim of our study was to characterize T1D patients with the comorbidity of PCOS within the DPV cohort with regard to diabetes phenotype, therapy and metabolic control.

Design and Setting: Clinical data from the prospective German/Austrian DPV cohort on patients with T1D and documented PCOS ( $n=76)$ were compared to female T1D controls $(n=32,566)$ in reproductive age.

Results: The age at T1D manifestation in PCOS patients was later than in the control group (14.9 \pm 8.2 vs. $11.8 \pm$ 7.0 years, $p<0.001)$. PCOS patients had higher BMI-SDS $(0.92 \pm 0.11$ vs. $0.38 \pm 0.01, p<0.001)$, metformin and oral contraceptives were used more frequently $(p<0.001)$. A1c levels were significantly lower $(7.92+/-0.23 \%$ vs. $8.43 \pm 0.01 \%, p<0.05)$ despite of lower insulin requirements $(0.76 \pm 0.04 \mathrm{IU} / \mathrm{kg} / \mathrm{d} \mathrm{vs.} 0.84 \pm 0.00 \mathrm{IU} / \mathrm{kg} / \mathrm{d}, \mathrm{p}$ $<0.05$ ). In the PCOS group, higher rates of dyslipidemia (63.4 vs. $48.7 \%, p=0.032)$ and thyroid disorders $(42.2 \%$ vs. $21.2 \%, p<0.001$ ) were present.

Discussion: While patients with T1D and comorbid PCOS showed features of a "type 1.5 diabetes" phenotype, insulin requirements per kg body weight were not higher and metabolic control was better, which could be explained only partially by additional metformin therapy. A more precise genetic and metabolic characterisation of these patients is needed to answer open questions on the underlying autoimmune process and residual ß-cell function.

\section{Keywords}

Diabetes $<$ Autoimmunity

Polycystic ovary syndrome $<$ Hormones

Obesity 


\section{Introduction}

The polycystic ovary syndrome (PCOS) is one of the most important reasons for female infertility and a common metabolic disorder [1]. According to several cross-sectional studies, $6-15 \%$ of the female population of childbearing age worldwide suffer from PCOS [2], while an unknown percentage is still undiagnosed. Prevalence depends on the genetic and socioeconomic background as well as the criteria used for diagnosis The common definitions (Rotterdam ESHRE/ASRM-Sponsored PCOS consensus workshop 2004 [3]) share hyperandrogenism as a central feature, besides oligo-/anovulation and a polycystic morphology of the ovaries on ultrasound examination, with two out of three criteria required in adults. Adolescents in particular should exhibit clinical or laboratory androgen excess, as anovulation and polycystic ovaries may physiologically occur in puberty, and the latter do not belong to the diagnostic criteria [4]. Other causes of androgen excess or related disorders such as non-classic adrenal 21-hydroxylase deficiency, hyperprolactinemia, or androgen secreting neoplasm have to be ruled out before making the diagnosis [5]. More than $40 \%$ of PCOS patients are insulin resistant, measured by patch clamp, OGTT or HOMA-index [6]. While an association of PCOS with the spectrum of impaired glucose tolerance to type 2 diabetes (T2D) is well established [7] the scope of this study is to investigate the clinical presentation of combined insulin dependent type 1 diabetes (T1D) and PCOS. A recent meta-analysis of nine studies showed a higher prevalence of PCOS in patients with T1D compared to the general population and a cumulative incidence of up to $24 \%$ [8]. Although in T1D increased androgen levels, menstrual abnormalities and delayed puberty are common, it is assumed that currently many PCOS cases in T1D are undiagnosed. The consequences of the comorbidity for the diabetes disease are unknown and a general or selective screening for PCOS is not yet implemented in T1D clinical practice guidelines.

\section{Objective}

To date there have been few data on clinical care of T1D patients with PCOS. Aim of the study was to analyse within the DPV database diabetes phenotype, therapy and metabolic control of female patients with T1D in reproductive age with or without documented PCOS.

\section{Research design, methods}

Research design 
We performed an observational cross sectional multicentre analysis of patients with T1D and PCOS between age 12 and 40 years and compared data to female T1D subjects without PCOS registered in the German/Austrian DPV database (Diabetes Patienten Verlaufsdokumentation). DPV is a nationwide prospective population-based registry of 437.289 patients (June 2016) with any type of diabetes in 446 centres in Germany, Luxemburg, Switzerland and Austria. Data are collected during routine care, anonymized and updated twice a year at a central administrative unit at the University of Ulm, Germany. The DPV has the ethical approval at the University of Ulm plus local data safety approval.

\section{Patients}

Within the study population 76 female patients with the documented diagnosis of both T1D and PCOS were identified. This cohort was compared to 32,566 female patients with T1D, but without the documented diagnosis of PCOS in the same age group (12-40 years). Diabetes duration was at least 6 months in all patients.

\section{Calculations/definitions}

Body mass index (BMI) values in these female patients were adjusted for age. Sex-specific standard deviation scores for BMI were calculated with national reference data from the German Health Interview and Examination Survey for Children and Adolescents and the German National Nutrition Survey for Adults [9; 10]. Glycated hemoglobin (A1C) was tested by the local laboratories and results were adjusted to the Diabetes Control and Complication Trial (DCCT) reference range (20-42 mmol/mol [4.05-6.05 \%]) for comparability [11]. The total daily insulin dose was calculated as units per body weight $(\mathrm{kg})$ per day. Dyslipidemia was defined by total cholesterol levels $>200 \mathrm{mg} / \mathrm{dl}, \mathrm{HDL}<35 \mathrm{mg} / \mathrm{dl}, \mathrm{LDL}>130 \mathrm{mg} / \mathrm{dl}$ or triglycerides $>150 \mathrm{mg} / \mathrm{dl}$. Thyroid disease was defined by clinical diagnosis of thyroid disease or laboratory diagnosis of autoimmune thyroid disease (TPO, TG or TRAK antibodies). The clinical diagnosis of PCOS was made by the treating physicians in the individual centres and documented in the DPV registry.

\section{Statistics}

Analyses were performed with the SAS 9.4 statistical software package (SAS Institute Inc., Cary, USA). Unadjusted data are presented as mean $+/$ SD or percentage. $P$-values for continuous data were determined by 
Wilcoxon, $p$-values for categorical variables by chi-square test, and $p$ was corrected for multiple comparisons (false discovery rate). $p<0.05$ was considered as statistically significant in a two-sided test. Additionally, linear and logistic regression models were used to adjust comparisons for age $(12-<20,20-<40$ years $)$ and diabetes duration ( $<5,>=5$ years). Adjusted data were presented as mean $+/$ - SEM or percentage.

\section{Results}

Age at diabetes manifestation

Patients in the PCOS group had a significantly and clinically relevant later onset of diabetes at a mean age of 14.9 instead of 11.5 years $(p<0,001)$. For $85.3 \%$ of all patients, positive ß-cell specific autoantibodies were documented, with no significant difference between the two groups.

\section{Weight}

Obesity was more common in T1D patients with PCOS. In PCOS BMI and BMI-SDS were significantly higher compared to control T1D patients. Body weight differed between the groups, PCOS patients weighing about $6 \mathrm{~kg}$ more, while height was similar (PCOS 164.1 vs. controls $165.0 \mathrm{~cm}$, n.s.).

\section{Hypertension and late complications}

The prevalence of arterial hypertension did not differ among groups. We saw no significant difference in the incidence of albuminuria or retinopathy (no documented case in PCOS vs. $6.4 \%$ in controls, n.s.) as markers of current microvascular disease.

\section{Dyslipidemia}

Patients with PCOS exhibited a significantly higher rate of dyslipidemia or taking lipid lowering drugs. Dyslipidemia rates did not differ significantly between PCOS patients using metformin therapy and those without (table 2).

\section{Associated disease}

More than 4 in 10 patients with PCOS showed thyroid disorders, about twice as much as T1D controls, defined by the diagnosis of thyroid disease, and/or positive autoantibodies. While the frequency of thyroid autoantibodies 
was not significantly higher, medication with levothyroxine or iodine was significantly more common in the PCOS group (table 1, $p=0.006$ ). TSH levels were similar and in the normal range in both groups (PCOS $2.2+/-0.9$ and $2.4+/-0.04 \mu \mathrm{U} / \mathrm{ml}$ without PCOS, n.s.). The prevalence of other autoimmune diseases such as rheumatoid arthritis, chronic inflammatory bowel disease, multiple sclerosis, pernicious anemia or adrenal autoantibodies in our cohort was too low to make sensible comparisons. We did not observe any patient with celiac disease within the PCOS group.

\section{Treatment}

Hormonal contraceptives were used by one in three PCOS patients, three times more often than in patients without PCOS (table 1). Although BMI and BMI-SDS were higher in the PCOS group, the total daily amount of insulin was similar. PCOS patients did not show higher insulin doses per kg bodyweight than controls (table 1). Metformin was more extensively used in the PCOS group. While $21 \%$ of PCOS patients were using metformin, only $1.2 \%$ of all female T1D patients were on biguanid therapy (table $1, p<0.001$ ). Within the PCOS group those patients with metformin use had a higher body weight and a significantly higher BMI-SDS. Patients on metformin used conventional insulin therapy (CT) more often and had a lower daily insulin dose for body weight, however not quite significant. PCOS patients without metformin had similar insulin requirements as controls (table 2).

\section{Metabolic control}

Overall metabolic control was only partially sufficient, with A1c above target of 7-7.5\% in both groups. A1c levels were significantly better in the PCOS group (table 1), where both patients with and without metformin had a significantly better A1c than controls (table 2).

\section{Discussion}

The aim of our study was to characterize T1D patients with the comorbid PCOS within the DPV database with regard to diabetes phenotype, therapy and metabolic control. Therefore, we identified females with both diagnoses in the DPV registry and compared their data to T1D patients without PCOS. As expected, patients with T1D and PCOS were more overweight and showed a higher rate of dyslipidemia. More patients in the PCOS group were taking oral contraceptives, possibly mainly because of the antiandrogenic effects. 


\section{Pathophysiology}

The age of diabetes onset in the PCOS group was delayed by more than three years. This was an unexpected finding, and in contrast to previous data [14; 15]. A possible explanation is that the pathogenesis of T1D is different in those patients with PCOS. There might be a different genetic background with respect to the underlying autoimmune process. We saw a similar frequency of beta-cell autoimmunity and autoimmune thyroid disorders, but no celiac disease in our T1D-PCOS cohort. This supports the hypothesis of a lower prevalence of T1D or celiac disease specific high risk HLA-alleles (HLA-DR3/4-DQ2/8) in the PCOS group. Patients with PCOS might be more prone for a different kind of autoimmunity compared to the T1D cohort in general. Only genotyping of PCOS patients for HLA-alleles and other T1D associated genes could finally clarify these questions on the genetic background.

It is unclear to date, whether patients develop (subclinical) PCOS or T1D first. Considering pathophysiology, insulin resistance associated with PCOS might be a driving factor for development of T1D comparable to the "accelerator hypothesis" [12; 13]. The surprisingly high percentage of patients on conventional insulin therapy (CT) fits a T2D-like phenotype.

On the other hand, PCOS might also be a secondary phenomenon to diabetes, triggered by high doses of insulin, administered subcutaneously in a non-physiological fashion surpassing the hepatic first pass mechanism [14; 15]. Insulin exerts a trophic action on ovary cells [16; 17] and drives the vicious circle of PCOS. Moreover, girls with T1D onset in puberty show rapid weight gain [18] which may lead to obesity related complications and comorbidities like PCOS. Regardless of what comes first, the T1D-PCOS cohort shows features of type 1.5 diabetes, with both autoimmunity and traits of a T2D phenotype [19;20].

\section{Implications for treatment}

Patch clamp studies were able to show that PCOS women have significant insulin resistance which is independent of adiposity [21]. Surprisingly, our clinical practice data do not show higher insulin requirements in T1D patients with PCOS. Although PCOS patients were overweight in our cohort, metabolic control was even better than in T1D controls with similar insulin requirements. This could be explained by a less aggressive autoimmune disease and a persisting beta-cell-function. Unfortunately, we do not have sufficient data available 
on C-peptide in the cohort. PCOS patients with and without metformin had a better A1c than controls, so favourable metabolic control can only be explained in part by metformin therapy (table 2). While T1D patients in total did not show a significant benefit from metformin therapy [22-25] our subgroup of PCOS patients seemed to benefit in terms metabolic control and experiences an insulin sparing effect, compensating for otherwise higher insulin requirements in a disease commonly associated with insulin resistance. Notably metformin treatment was more commonly initiated in obese patients, so our data cannot provide information on whether lean T1D women with PCOS will equally benefit with regard to metabolic control. There might be a benefit in fertility treatment, where metformin can be added to clomiphene or used alone [26;27] and therefore a subgroup of the women in our cohort will use metformin not only for improvement of metabolic control but also to induce pregnancy. All women were in reproductive age, and those who desire to have children may be more disciplined in terms of treatment, eating habits and lifestyle and this might have influenced metabolic control in addition to a direct effect of metformin.

Of note, we saw a high rate of thyroid disorders in PCOS patients. While a high prevalence of autoimmune thyroid disorders in PCOS patients was described previously [28], many women might however be treated with levothyroxine for fertility treatment or for obesity-associated hyperthyrotropinemia. Still, not only in diabetes but also in PCOS in general a screening for autoimmune thyroiditis or hypothyroidism should be considered

\section{Screening}

Escobar-Morreale et al. warn that PCOS is the most commonly missed comorbidity in T1D patients as screening is not yet implemented, while incidence is high [8]. In his meta-analysis of nine studies, $24 \%$ (Cl 15-34) of T1D patients were diagnosed with PCOS. Our prevalence was much lower, reflecting a certain degree of underdiagnosis or underreportation, although it has to be taken into account that prevalence depends on the ethnic background and patients were young, while diagnosis is often delayed. Despite clinical practice guidelines recommendations to screen PCOS patients for diabetes, neither T1D nor T2D patients are currently screened for PCOS $[29 ; 30]$.

PCOS belongs to the most common comorbidities, and even without general screening diabetologists should include evaluation of menstrual abnormalities or clinical hyperandrogenism (hirsutism, acne) in their routine examinations as already practised for other comorbidities as hypertension, dyslipidemia, celiac and thyroid 
disorders to gain a better understanding of this patient group. While some patients have no metabolic comorbidities, especially those $50-70 \%$ PCOS patients at risk, who exhibit obesity, dyslipidemia, hypertension and insulin resistance, have an elevated risk for cardiovascular diseases. The higher rate oral contraceptive use may add up to the elevated risk for cardiovascular diseases in women with diabetes. It is currently unknown whether an added cardiovascular risk arises from PCOS diagnosis in normal weight women with type 1 diabetes who have no other cardiovascular risk factors [8].

\section{Limitations}

This study has some limitations. First, due to potential underreporting of secondary diagnoses, the true prevalence of PCOS in T1D patients in the DPV registry may be higher. We deliberately decided not to include patients without the documented diagnosis of PCOS but isolated findings such as anovulation, hirsutism, infertility etc., though this would have yielded a higher patient number. Also, the database does not allow to conclude whether PCOS or T1D developed first.

A second limitation is that we have no information about body composition (body fat, waist circumference) or regularity of menses available and miss laboratory data on steroid hormones. The data available in the registry are the diabetes-specific clinical parameters on which this study has focused.

\section{Conclusion}

Patients diagnosed with PCOS and T1D presented with diabetes later in life, showed lower insulin requirements and a better metabolic control compared to T1D patients without PCOS. They demonstrated features of type 1.5 diabetes. Screening for PCOS should be implemented in the clinical care of female adolescents and adults with T1D, as this comorbidity is common, and the early diagnosis may have implications for evaluating the cardiovascular risk and deciding on additional metformin treatment, which appears to be beneficial in these patients. In terms of pathogenesis of the PCOS in female patients with T1D our data raises open questions concerning the underlying autoimmune process and the residual beta-cell function. A deeper genetic and metabolic characterisation of these patients is needed for a better understanding.

\section{Acknowledgements}


We would like to thank the centres listed in the appendix for participating in the DPV initiative and contributing their data to this study. The DPV database is supported by the BMBF German Federal Ministry of Education and Research as part of the German Competence Network Diabetes Mellitus (FKZ 01GI1106), which was integrated into the German Centre for Diabetes Research (DZD). Additional funding was provided by the European Foundation for the Study of Diabetes (EFSD), the German Diabetes Association (DDG), the Heinz Bürger-Büsing foundation and the EU-IMI-projects DIRECT and INNODIA. 


\section{References}

1 Teede H, Deeks A, Moran L. Polycystic ovary syndrome: a complex condition with psychological, reproductive and metabolic manifestations that impacts on health across the lifespan. BMC Med 2010; 8: 41

2. Asunción M, Calvo RM, San Millán JL, Sancho J, Avila S, Escobar-Morreale HF. A prospective study of the prevalence of the polycystic ovary syndrome in unselected Caucasian women from Spain. J Clin Endocrinol Metab 2000; 85(7):2434-8

3. Rotterdam ESHRE/ASRM-Sponsored PCOS Consensus Workshop Group. Revised 2003 consensus on diagnostic criteria and long-term health risks related to polycystic ovary syndrome. Fertil Steril 2004; 81(1): $19-25$

4. Legro RS, Arslanian SA, Ehrmann DA, Hoeger KM, Murad MH, Pasquali R et al. Diagnosis and treatment of polycystic ovary syndrome: An Endocrine Society clinical practice guideline. J Clin Endocrinol Metab 2013; 98(12): 4565-92

5. Zawadsky J, Dunaif A. Diagnostic criteria for polycystic ovary syndrome. In: Dunaif A, Givens JR, Haseltine FP, Merriam GR, ed. Polycystic ovary syndrome. Boston: Blackwell Scientific, 1992: 377-84 6. Legro RS, Castracane VD, Kauffman RP. Detecting insulin resistance in polycystic ovary syndrome: purposes and pitfalls. Obstet Gynecol Surv 2004; 59(2): 141-54

7. Salley KE, Wickham EP, Cheang KI, Essah PA, Karjane NW, Nestler JE. Glucose intolerance in polycystic ovary syndrome-a position statement of the Androgen Excess Society. J Clin Endocrinol Metab 2007; 92 : $4546-4556$

8. Escobar-Morreale HF, Roldán-Martín MB. Type 1 Diabetes and Polycystic Ovary Syndrome: Systematic Review and Meta-analysis. Diabetes Care 2016; 39(4): 639-48

9. Rosario A. S., Kurth B.-M., Stolzenberg H., Ellert U., Neuhauser H. Body mass index percentiles for children and adolescents in Germany based on a nationally representative sample (KiGGS 2003-2006). Eur J Clin Nutrition 2010; 64(4): 341-349

10. Hemmelmann C, Brose S, Vens M, Hebebrand J, Ziegler A. Percentiles of body mass index of 18-80-yearold German adults based on data from the Second National Nutrition Survey Dtsch med Wochenschr 2010; 135(17): 848-852 
11. Gerstl EM, Rabl W, Rosenbauer J, Gröbe H, Hofer SE, Krause U et al. Metabolic control as reflected by $\mathrm{HbA1c}$ in children, adolescents and young adults with type-1 diabetes mellitus: combined longitudinal analysis including 27.035 patients from 207 centers in Germany and Austria during the last decade. Eur J Pediatr 2008; 167(4): 447-53

12. Knerr I, Wolf J, Reinehr T, Stachow R, Grabert M, Schober E et al. The 'accelerator hypothesis': relationship between weight, height, body mass index and age at diagnosis in a large cohort of 9,248 German and Austrian children with type 1 diabetes mellitus. Diabetologia 2005; 48(12): 2501-4

13. Gale EA. To boldly go-or to go too boldly? The accelerator hypothesis revisited. Diabetologia 2007; 50(8): $1571-5$

14. Codner E, Soto N, Lopez P, Trejo L, Avila A, Eyzaguirre FC et al. Diagnostic criteria for polycystic ovary syndrome and ovarian morphology in women with type 1 diabetes mellitus. J Clin Endocrinol Metab 2006; 91(6): $2250-6$

15. Escobar-Morreale HF, Roldán B, Barrio R, Alonso M, Sancho J, de la Calle H et al. High prevalence of the polycystic ovary syndrome and hirsutism in women with type 1 diabetes mellitus. J Clin Endocrinol Metab 2000; 85(11): 4182-7

16. Veldhuis JD, Klase PA, Sandow BA, Kolp LA. Progesterone secretion by highly differentiated human granulosa cells isolated from preovulatory Graafian follicles induced by exogenous gonadotropins and human chorionic gonadotropin. J Clin Endocrinol Metab 1983; 57(1): 87-93

17. Cara JF, Rosenfield RL. Insulin-like growth factor I and insulin potentiate luteinizing hormone-induced androgen synthesis by rat ovarian thecal-interstitial cells. Endocrinology 1988; 123(2): 733-9

18. Fröhlich-Reiterer EE, Rosenbauer J, Bechtold-Dalla Pozza S, Hofer SE, Schober E, Holl RW et al. Predictors of increasing BMI during the course of diabetes in children and adolescents with type 1 diabetes: data from the German/Austrian DPV multicentre survey. Arch Dis Child 2014; 99(8): 738-43

19. Pozzilli P, Guglielmi C, Caprio S, Buzzetti R. Obesity, autoimmunity, and double diabetes in youth. Diabetes Care 2011; 34 (2): S166-70

20. Cleland SJ, Fisher BM, Colhoun HM, Sattar N, Petrie JR. Insulin resistance in type 1 diabetes: what is 'double diabetes' and what are the risks? Diabetologia 2013; 56(7): 1462-70

21. Park KH, Kim JY, Ahn CW, Song YD, Lim SK, Lee HC. Polycystic ovarian syndrome (PCOS) and insulin 
resistance. Int J Gynaecol Obstet 2001; 74(3): 261-7

22. Vella S, Buetow L, Royle P, Livingstone S, Colhoun HM, Petrie JR. The use of metformin in type 1 diabetes: a systematic review of efficacy. Diabetologia 2010; 53(5):809-20

23. Konrad K, Datz N, Engelsberger I, Grulich-Henn J, Hoertenhuber T, Knauth B et al. Current use of metformin in addition to insulin in pediatric patients with type 1 diabetes mellitus: an analysis based on a large diabetes registry in Germany and Austria. Pediatr Diabetes 2015; 16(7): 529-37

24. Libman IM, Miller KM, DiMeglio LA et al for the T1D Exchange Clinic Network Metformin RCT Study Group Effect of metformin added to insulin on glycemic control among overweight/obese adolescents with type 1 diabetes - a randomized clinical trial. JAMA 2015; 314(21): 2241-2250

25. Naderpoor N, Shorakae S, de Courten B, Misso ML, Moran LJ, Teede HJ. Metformin and lifestyle modification in polycystic ovary syndrome: systematic review and meta-analysis. Hum Reprod Update 2015; 21(5): 560-74

26. Palomba S, Orio F Jr, Falbo A, Manguso F, Russo T, Cascella T et al. Prospective parallel randomized, double-blind, double-dummy controlled clinical trial comparing clomiphene citrate and metformin as the firstline treatment for ovulation induction in nonobese anovulatory women with polycystic ovary syndrome. J Clin Endocrinol Metab 2005; 90(7): 4068-74

27. Balen AH, Morley LC, Misso M, Franks S, Legro RS, Wijeyaratne CN et al. The management of anovulatory infertility in women with polycystic ovary syndrome: an analysis of the evidence to support the development of global WHO guidance. Hum Reprod Update 2016; 22(6): 687-708.

28. Novais Jde S, Benetti-Pinto CL, Garmes HM, Jales RM, Juliato CR. Polycystic ovary syndrome and chronic autoimmune thyroiditis. Gynecol Endocrinol 2015; 31(1): 48-51

29. McCartney CR, Marshall JC. CLINICAL PRACTICE. Polycystic Ovary Syndrome. N Engl J Med 2016; 375(1): $54-64$

30. Goodman NF, Cobin RH, Futterweit W, Glueck JS, Legro RS, Carmina E et al., American association of clinical endocrinologists, American college of endocrinology, and androgen excess and PCOS society disease state clinical review: Guide to the best practices in the evaluation and treatment of polycystic ovary syndrome. Part 2. Endocr Pract 2015; 21(12): 1415-26 


\begin{tabular}{|l|l|l|l|}
\hline & T1D and PCOS & T1D only & adjusted p-value \\
\hline All patients [n] & 76 & 32.566 & \\
\hline Age [years] & $24.6 \pm 7.6$ & $20.0 \pm 7.2$ & $<0.001^{*}$ \\
\hline Age at diabetes onset [years] & $14.9 \pm 8.2$ & $11.5 \pm 7.0$ & $<0.001^{*}$ \\
\hline Duration of diabetes [years] & $9.7 \pm 7.4$ & $8.5 \pm 6.6$ & n.s. $(0.44)^{*}$ \\
\hline Weight [kg] & $72.9 \pm 1.6$ & $65.1 \pm 0.1$ & $<0.001$ \\
\hline BMI [kg/m²] & $26.78 \pm 0.52$ & $23.83 \pm 0.02$ & $<0.001$ \\
\hline BMI-SDS & $0.92 \pm 0.11$ & $0.38 \pm 0.01$ & $<0.001$ \\
\hline A1c [\%] dosage [IU/kg body & $7.93 \pm 0.23$ & $8.43 \pm 0.01$ & 0.031 \\
\hline $\begin{array}{l}\text { Insulin } \\
\text { weight/d] }\end{array}$ & $0.77 \pm 0.04$ & $0.84 \pm 0.002$ & n.s. $(0.11)$ \\
\hline Absolute insulin dosage [IU/d] & $54.53 \pm 2.77$ & $53.56 \pm 0.13$ & n.s. $(0.73)$ \\
\hline Thyroid disease [\%] & $42.2 \pm 5.8$ & $21.2 \pm 0.2$ & $<0.001$ \\
\hline Thyroid antibodies [\%] & $19.9+/-6.8$ & $28.7+/-0.4$ & n.s. $(0.26)$ \\
\hline Thyroid medication [\%] & $26.9 \pm 5.4$ & $14.7 \pm 0.2$ & 0.006 \\
\hline $\begin{array}{l}\text { Dyslipidemia/ lipid lowering } \\
\text { medication [\%] }\end{array}$ & $63.4 \pm 6.5$ & $48.7 \pm 0.3$ & 0.032 \\
\hline $\begin{array}{l}\text { Hypertension/ antihypertensive } \\
\text { medication [\%] }\end{array}$ & $17.2 \pm 4.3$ & $13.4 \pm 0.2$ & n.s. $(0.33)$ \\
\hline Oral contraceptives [\%] & $35.6 \pm 5.7$ & $11.2 \pm 0.2$ & $<0.001$ \\
\hline Metformin [\%] & $21.0 \pm 4.5$ & $1.2 \pm 0.0$ & $<0.001$ \\
\hline Microalbuminuria [\%] & $15.6 \pm 5.1$ & $13.2 \pm 0.2$ & n.s. $(0.61)$ \\
\hline
\end{tabular}

Table 1: Comparison of female patients with T1D and documented PCOS versus T1D only. Data are shown as mean \pm SD/SEM or percentage $\left({ }^{*}=\right.$ unadjusted data, other comparisons are adjusted for age and T1D-duration)

\begin{tabular}{|l|l|l|l|}
\hline & $\begin{array}{l}\text { PCOS and metformin } \\
(\mathbf{n}=19)\end{array}$ & $\begin{array}{l}\text { PCOS/no metformin } \\
(\mathbf{n}=57)\end{array}$ & adjusted p-value \\
\hline Weight [kg] & $79.4 \pm 3.4$ & $73.4 \pm 2.1$ & n.s. (0.13) \\
\hline BMI [kg/m²] & $29.4 \pm 1.1$ & $26.6 \pm 0.7$ & 0.043 \\
\hline BMI-SDS & $1.20 \pm 0.21$ & $0.75 \pm 0.13$ & n.s. (0.08) \\
\hline A1c [\%] & $8.00 \pm 0.41$ & $7.76 \pm 0.23$ & n.s. (0.62) \\
\hline $\begin{array}{l}\text { Insulin dosage [IU/kg body } \\
\text { weight/d] }\end{array}$ & $0.58 \pm 0.07$ & $0.75 \pm 0.05$ & n.s. (0.051) \\
\hline Absolute insulin dosage [IU/d] & $44.7 \pm 5.4$ & $53.7 \pm 3.4$ & n.s. $(0.16)$ \\
\hline Conventional therapy/CT [\%] & $25.5 \pm 11.1$ & $2.1 \pm 2.3$ & 0.031 \\
\hline Oral contraceptives [\%] & $14.2 \pm 8.0$ & $35.1 \pm 6.8$ & n.s. $(0.10)$ \\
\hline $\begin{array}{l}\text { Dyslipidemia/ lipid lowering } \\
\text { medication [\%] }\end{array}$ & $61.6 \pm 15.1$ & $65.0 \pm 7.2$ & n.s. $(0.84)$ \\
\hline $\begin{array}{l}\text { Hypertension/ } \\
\text { antihypertensive medication } \\
\text { [\%] }\end{array}$ & $25.5 \pm 10.1$ & $16.4 \pm 5.1$ & n.s. (0.39) \\
\hline
\end{tabular}

Table 2: Comparison of female patients with T1D and PCOS with and without metformin therapy. Data are shown as mean \pm SEM or percentage 


\section{Collaborating DPV centers}

Augsburg Kinderklinik Zentralklinikum, Aachen - Uni-Kinderklinik RWTH, Ahlen St. Franziskus Kinderklinik, Aue Helios Kinderklink, Aurich Kinderklinik, Wien Uni-Kinderklinik, Weingarten Kinderarztpraxis, Berlin Lichtenberg Kinderklinik, Berlin Virchow-Kinderklinik, Berlin Vivantes Hellersdorf Innere, Berlin Klinik St. Hedwig Innere, Berlin Schlosspark-Klinik Innere, Bad Aibling Internist. Praxis, Bremerhaven Kinderklinik, Bielefeld Kinderklinik Gilead, Bonn Uni-Kinderklinik, Braunfels-Wetzlar Innere, Hinrichsegen-Bruckmühl Diabetikerjugendhaus, Bottrop Kinderklinik, Bottrop Knappschaftskrankenhaus Innere, Celle Klinik für Kinder- und Jugendmedizin, Chemnitz Kinderklinik, Coesfeld Kinderklinik, Düsseldorf Uni-Kinderklinik, Darmstadt Kinderklinik Prinz. Margaret, Deggendorf Pädiatrie-Praxis, Deggendorf Medizinische Klinik II, Bad Driburg / Bad Hermannsborn Innere, DürenBirkesdorf Kinderklinik, Delmenhorst Kinderklinik, Deggendorf Kinderklinik, Detmold Kinderklinik, Dortmund Kinderklinik, Dortmund-St. Josefshospital Innere, Dresden Uni-Kinderklinik, Datteln Vestische Kinderklinik, Essen Uni-Kinderklinik, Erlangen Uni-Kinderklinik, Erfurt Kinderklinik, Esslingen Klinik für Kinder und Jugendliche, Eutin St.-Elisabeth Innere, Eutin Kinderklinik, Frankfurt Uni-Kinderklinik, Offenbach/Main Kinderklinik, Freiburg UniKinderklinik, Friedberg Innere Klinik, Friedrichshafen Kinderklinik, Fürth Kinderklinik, Fulda Kinderklinik, Gaissach Fachklinik der Deutschen Rentenversicherung, Bayern Süd, Garmisch-Partenkirchen Kinderklinik, Gießen UniKinderklinik, Göppingen Kinderklinik am Eichert, Gelsenkirchen Kinderklinik Marienhospital, Göttingen UniKinderklinik, Görlitz Städtische Kinderklinik, Hannover Kinderklinik MHH, Hannover Kinderklinik auf der Bult, Hannover Henriettenstift - Innere, Halle Uni-Kinderklinik, Halle-Dölau Städtische Kinderklinik, Hachenburg Kinderpraxis, Hamm Kinderklinik, Bremen Zentralkrankenhaus Kinderklinik, Bremen - Kinderklinik Nord, Heilbronn Innere Klinik, Heidelberg Uni-Kinderklinik, Heidenheim Kinderklinik, Herford Klinikum Kinder \& Jugendliche, Bad Hersfeld Kinderklinik, Herzberg Kreiskrankenhaus Innere, Hermeskeil Kinderpraxis, Hagen Kinderklinik, Hamburg Altonaer Kinderklinik, Hamburg Kinderklinik Wilhelmstift, Hamburg-Nord Kinder-MVZ, Hildesheim Kinderklinik, Hildesheim Kinderarztpraxis, Liste der in diese Auswertung eingehenden Zentren, Lübeck Uni-Kinderklinik, Lübeck Uni-Klinik Innere Medizin, Homburg Uni-Kinderklinik Saarland, Hanau Kinderklinik, Itzehoe Kinderklinik, Jena Uni-Kinderklinik, Köln Uni-Kinderklinik, Karlsruhe Städtische Kinderklinik, Kaiserslautern-Westpfalzklinikum Kinderklinik, Karlsburg Klinik für Diabetes \& Stoffwechsel, Kempen Heilig Geist - Innere, Kiel Städtische Kinderklinik, Konstanz Innere Klinik, Koblenz Kinderklinik Kemperhof, Koblenz Kemperhof . Med. Klinik, Krefeld Innere Klinik, Bad Kreuznach-St. Marienwörth-Innere, Kassel Klinikum Kinderund Jugendmedizin, Leipzig Uni-Kinderklinik, Ludwigsburg Kinderklinik, Landshut Kinderklink, Lingen Kinderklinik St. Bonifatius, Lippstadt Evangelische Kinderklinik, Ludwigshafen Kinderklinik St. Anna-Stift, Lüdenscheid Märkische Kliniken - Kinder \& Jugendmedizin, München von Haunersche Kinderklinik, München-Harlaching Kinderklinik, Mannheim Uni-Kinderklinik, Mannheim Uniklinik Innere Medizin, Marburg Uni-Kinderklinik, Mechernich Kinderklinik, Minden Kinderklinik, Moers Kinderklinik, Mölln Reha-Klinik Hellbachtal, Münster pädiat. Schwerpunktpraxis, Münster Uni-Kinderklinik, Mutterstadt Kinderarztpraxis, Nürnberg Zentrum f Neugeb./Kinder \& Jugendl., Neuwied Kinderklinik Elisabeth, Neunkirchen Marienhausklinik Kohlhof Kinderklinik, Nürnberg Cnopfsche Kinderklinik, Oberhausen Kinderklinik, Oberhausen Innere, Oldenburg Kinderklinik, Osnabrück Christliches Kinderhospital, Bad Oeynhausen Herz-und Diabeteszentrum NRW, Paderborn St. Vincenz Kinderklinik, Pforzheim Kinderklinik, Regensburg Kinderklinik St. Hedwig, Remscheid Kinderklinik, Mönchengladbach Kinderklinik Rheydt Elisabethkrankenhaus, Rendsburg Kinderklinik, Rosenheim Kinderklinik, Rastatt Kreiskrankenhaus Innere, Rastatt Gemeinschaftspraxis, Ravensburg Kinderklink St. Nikolaus, Rotenburg/Wümme Agaplesion Diakonieklinikum, Kinderabteilung, Stuttgart Olgahospital Kinderklinik, Saalfeld Thüringenklinik Kinderklinik, aarlouis Kinderklinik, Saarbrücken Kinderklinik Winterberg, Schw. Gmünd Stauferklinik Kinderklinik, Suhl Kinderklinik, Siegen Kinderklinik, Singen - Hegauklinik Kinderklinik, Sinsheim Innere, Spaichingen Innere, Stade Kinderklinik, Sylt Rehaklinik, Trier Kinderklinik der Borromäerinnen, Ulm UniKinderklinik, Vechta Kinderklinik, Viersen Kinderkrankenhaus St. Nikolaus, Weiden Kinderklinik, Wiesbaden Kinderklinik DKD, Wiesbaden Helios Horst-Schmidt-Kinderkliniken, Herdecke Kinderklinik, Waldshut-Tiengen Kinderpraxis Biberbau, Winnenden Rems-Murr Kinderklinik, Worms Kinderklinik, Wuppertal Kinderklinik, Kassel Städtische Kinderklinik, Magdeburg Uni-Kinderklinik, Hanau St. Vincenz - Innere, Schweinfurt Kinderklinik, Hildesheim GmbH - Innere, Idar Oberstein Innere, Saaldorf-Surheim Diabetespraxis, Neuss Lukaskrankenhaus Kinderklinik, München-Schwabing Kinderklinik, Passau Kinderklinik, Neuburg Kinderklinik, Augsburg IV. Med. Klinik, Scheidegg Reha-Kinderklinik Maximilian, Rostock Universität Innere Medizin, Bad Lauterberg Diabeteszentrum Innere, Recklinghausen Dialysezentrum Innere, Frankfurt Uni-Klinik Innere, Rosenheim Innere Medizin, Memmingen Kinderklinik, Herten St. Elisabeth Innere Medizin, Innsbruck Uni-Kinderklinik, Bad Kösen Kinder-Rehaklinik, Kaufbeuren Innere Medizin, Ludwigsburg Innere Medizin, Wetzlar Schwerpunkt-Praxis, Tübingen Uni-Kinderklinik, Heringsdorf Inselklinik, Marburg - UKGM Endokrinologie \& Diabetes, Gelnhausen 
Kinderklinik, Asbach Kamillus-Klinik Innere, Merzig Kinderklinik, Lindenfels Luisenkrankenhaus Innere, Bad Reichenhall Kreisklinik Innere Med. Stolberg Kinderklinik, Münster St. Franziskus Kinderklinik, Passau Kinderarztpraxis, Berlin St. Josephskrankenhaus Innere, Bad Säckingen Hochrheinklinik Innere, Leverkusen Kinderklinik, Dornbirn Kinderklinik, Altötting Zentrum Inn-Salzach, Eberswalde Klinikum Barnim Werner Forßmann - Innere, Offenburg Kinderklinik, Nidda Bad Salzhausen Klinik Rabenstein/Innere- Reha, Kiel Universitäts-Kinderklinik, Kirchheim-Nürtingen Innere, Herne Evan. Krankenhaus Innere, Güstrow Innere, Duisburg Malteser Rhein-Ruhr St. Anna Innere, Mühlacker Enzkreiskliniken Innere, Neuwied Marienhaus Klinikum St. Elisabeth Innere, Rostock Uni-Kinderklinik, Wilhelmshaven St. Willehad Innere, Bocholt Kinderklinik, Oberhausen Kinderpraxis, Schwerin Kinderklinik, Fulda Innere Medizin, Rheine Mathiasspital Kinderklinik, Essen Elisabeth Kinderklinik, Mainz Uni-Kinderklinik, Traunstein diabetol. Schwerpunktpraxis, Villingen-Schwenningen Schwarzwald-Baar-Klinikum Innere, Herford Kinderarztpraxis, München-Gauting Kinderarztzentrum, Magdeburg Städtisches Klinikum Innere, Moers - St. Josefskrankenhaus Innere, Papenburg Marienkrankenhaus Kinderklinik, Wilhelmshaven Klinikum Kinderklinik, Bochum Universitätskinderklinik St. Josef, Köln Kinderklinik Amsterdamerstrasse, Landau/Annweiler Innere, Heilbronn Kinderklinik, Chemnitz-Hartmannsdorf Innere Medizin - DIAKOMED-, Kassel Rot-Kreuz-Krankenhaus Innere, Graz Uni-Kinderklinik, München Diabetes-Zentrum Süd, Dortmund Knappschaftskrankenhaus Innere, Krefeld Kinderklinik, Rosenheim Schwerpunktpraxis, Timmendorfer Strand, Reutlingen Klinikum Steinenberg Innere, Bad Waldsee Kinderarztpraxis, Berlin Oskar Zieten Krankenhaus Innere, Aalen Kinderklinik, Duisburg Evang. und Johanniter Krhs Innere, Schwerin Innere Medizin, Wolgast Innere Medizin, Geislingen Klinik Helfenstein Innere, Kirchen DRK Krankenhaus Kinderklinik, Berlin DRK-Kliniken Pädiatrie, München. Orden Kinderklinik, Darmstadt Innere Medizin, Bautzen Oberlausitz KK, Hamburg Endokrinologikum, Freiburg Uni Innere, Rüsselsheim Kinderklinik, Trostberg Innere, Oy-Mittelberg Hochgebirgsklinik Kinder-Reha, Berchtesgaden CJD, St. Augustin Kinderklinik, Wernberg-Köblitz SPP, Tettnang Innere Medizin, Frankenthal Kinderarztpraxis, Göppingen Innere Medizin, Dresden Neustadt Kinderklinik, Osterkappeln Innere, Berchtesgaden MVZ Innere Med, Haren Kinderarztpraxis, Bad Mergentheim Gemeinschaftspraxis DM-dorf Althausen, Konstanz Kinderklinik, Heidenheim Arztpraxis Allgemeinmed, Waldshut Kinderpraxis, Gera Kinderklinik, Reutlingen Kinderarztpraxis, Heidelberg Uniklinik Innere, Arnsberg-Hüsten Karolinenhosp. Kinderabteilung, Schwäbisch Hall Diakonie Kinderklinik, Oldenburg Schwerpunktpraxis, Hof Kinderklinik, Gelnhausen Innere, Bremen - Mitte Innere, Kreischa-Zscheckwitz Klinik Bavaria, Linz Krankenhaus der Barmherzigen Schwestern Kinderklinik, Nauen Havellandklinik, Ulm Schwerpunktpraxis Bahnhofsplatz, Pirmasens Städtisches Krankenhaus Innere, Ingolstadt Klinikum Innere, Hameln Kinderklinik, Limburg Innere Medizin, Heide Kinderklinik, München Kinderarztpraxis diabet. SPP, Iserlohn Innere Medizin, Prenzlau Krankenhaus Innere, Dortmund Medizinische Kliniken Nord, Ulm Endokrinologikum, Linz Krankenhaus Barmherzige Schwestern Kardiologie Abt., Bad Orb Spessart Klinik Reha, Weisswasser Kreiskrankenhaus, Frankfurt Diabeteszentrum, Rhein-Main-Erwachsenendiabetologie (Bürgerhospital), Wittenberg Kinderklinik, Mödling Kinderklinik, St. Pölten Universitäts-Kinderklinik, Braunschweig Kinderarztpraxis, Berlin Endokrinologikum, Pfullendorf Innere Medizin, Kleve Innere Medizin, Bayreuth Innere Medizin, Böblingen Kinderklinik, Lünen Klinik am Park, Gießen Ev. Krankenhaus Mittelhessen, Oschersleben MEDIGREIF Bördekrankenhaus, Plauen Vogtlandklinikum, Ottobeuren Kreiskrankenhaus, Duisburg Malteser St. Johannes, Berlin Evang. Krankenhaus Königin Elisabeth, Aachen - Innere RWTH, Neunkirchen Innere Medizin, Herford Innere Med I, Altötting-Burghausen Innere Medizin, Bad Salzungen Kinderklinik, Bad Mergentheim Diabetesfachklinik, Schwäbisch Hall Diakonie Innere Medizin, Erlangen Uni Innere Medizin, Reutlingen Kinderklinik, Coesfeld/Dülmen Innere Med., Villach Kinderklinik, Bad Krozingen Klinik Lazariterhof Park-Klinikum, Wittenberg Innere Medizin, Frankfurt Diabeteszentrum Rhein-Main-pädiat. Diabetologie, (Clementine-Hospital), Forchheim Diabeteszentrum SPP, Ulm Uni Innere Medizin, Bad Hersfeld Innere, Marpingen-SPP, Salzburg Universitäts-Kinderklinik, Wien Uni Innere Med III, Scheidegg Prinzregent Luitpold, Wien Preyersches Kinderspital, Offenbach/Main Innere Medizin, Kaiserslautern Kinderarztpraxis, München Schwerpunktpraxis, Wien . Med. Hietzing Innere, Leoben LKH Kinderklinik, Duisburg-Huckingen, Münster Herz Jesu Innere, Marktredwitz Innere Medizin, Krefeld-Uerdingen St. Josef Innere, Wien Wilhelminenspital. Med. Abteilung, Wien SMZ Ost Donauspital, Wien Rudolfstiftung, Villingen-Schwenningen SPP, Worms - Weierhof, Dornbirn Innere Medizin, Linz Landes-Kinderklinik, Wels Klinikum Pädiatrie, Duisburg Sana Kinderklinik, Villingen-Schwenningen Schwarzwald Baar Klinikum, Kinderklinik, Kamen Klinikum Westfalen Hellmig Krankenhaus, Freiburg St. Josef Kinderklinik, Feldkirch Kinderklinik, Lappersdorf Kinderarztpraxis, Ludwigshafen diabetol. SPP, Oberhausen St.Clemens Hospitale Sterkrade, Dortmund-Hombruch Marienhospital, Dessau Kinderklinik, Murnau am Staffelsee - diabetol. SPP, Luxembourg - Centre Hospitalier, St. Pölten niversitätsklinik Innere, Bad Orb Spessart Klinik, Neumarkt Innere, Krefeld Alexianer Innere, Innsbruck Universitätsklinik Innere, Bad KreuznachViktoriastift, Lindenfels Luisenkrankenhaus Innere, Lüdenscheid Hilfswerk Kinder \& Jugendliche, Eisleben 
Lutherstadt Helios-Klinik, Lienz Diabetesschwerpunktpraxis für Kinder und Jugendliche, Olpe pädiatrische Gemeinschaftspraxis, Lilienthal Diabeteszentrum, Waren-Müritz Kinderklinik, Aidlingen Praxisgemeinschaft, Berlin Parkklinik Weissensee, Freiburg Kinder-MVZ, Heidelberg St. Josefskrankenhaus, Duisburg-St.Johannes Helios, Lienz BKH Kinderklinik, Essen Diabetes-Schwerpunktpraxis, Wels Innere, Münster Clemens-Hospital Innere, Zweibrücken Ev. KH. Innere, Dortmund-West Innere, Leer Kreiskrankenhaus - Kinderabt., CastropRauxel Rochus-Hospital, Singen Kinderarztpraxis, Dinslaken Kinderklinik, Kempten Oberallgäu Kinderklinik, Linz AKH. Med, Freudenstadt Kinderklinik, Halberstadt Kinderklinik AMEOS, Halberstadt Innere Med. AMEOS Klinik, Bruchweiler Edelsteinklinik Kinder-Reha, Wismar Kinderklinik, Coburg Kinderklinik, Essen Kinderarztpraxis, Filderstadt Kinderklinik, Meissen Kinderklinik Elblandklinikum, Greifswald Uni-Kinderklinik, Ried Innkreis Barmherzige Schwestern, Duisburg-Huckingen Malteser Rhein-Ruhr ST. Johannes, Wangen Oberschwabenklinik Innere Medizin, Traunstein Kinderklinik, Augsburg Josefinum Kinderklinik, Amberg Kinderklinik St. Marien, Klagenfurt Innere Med I, Zweibrücken Kinderarztpraxis, Bern Universitätsklinik InselSpital Innere Medizin, Neuruppin Kinderklinik, Coburg Innere Medizin, Nürnberg Med. Klinik, Malchower See Rehaklinik, Bochum Universitäts St. Josef, Marburg Uni-Kinderklinik, Flensburg Diakonissen Kinderklinik, Berlin DRK-Kliniken Westend Innere, Frankfurt-Sachsenhausen Innere, Scheibbs Landesklinikum, Göttingen Uni Gastroenterologie, Deggendorf Gemeinschaftspraxis, Oberndorf Gastroenterologische Praxis Schwerpunkt, Diabetologie, Memmingen Internistische Praxis, Stockerau Landeskrankenhaus, Bielefeld Kinderarztpraxis, Frankfurt Uni-Klinik Innere, Landau Innere, Oberwart - Burgenländische Krankenanstalten Pädiatrie, Speyer Diakonissen Stiftungskrankenhaus Pädiatrie, Frankfurt-Sachsenhausen Innere MVZ 